\author{
JERZY EISLER \\ Institute of National Remembrance, Warsaw
}

\title{
BETTER NOT AT ALL THAN NOT WELL. A REVIEW OF A BIOGRAPHY OF WŁADYSŁAW GOMUŁKA*
}

\begin{abstract}
Abst ract: Władysław Gomułka was the Polish communist leader who, most probably, played the most important role in the history of Poland. In the years 1943-48 he was the Secretary of the Polish Workers' Party, and next, from 1956 to 1970, the First Secretary of the Central Committee of the Polish United Workers' Party. According to the rule 'the more power the more responsibility', which had particular significance in non-democratic systems, Gomulka was responsible or co-responsible for everything good but also for everything bad that happened in Poland during his rule. At the same time he is this Polish communist leader, on whose life and activity over twenty books were published. One of the recent ones was published by Anita Prażmowska. Unfortunately, this is not a successful attempt.

Ke yw ords: Władysław Gomułka 'Wiesław', communism, Polish United Workers' Party, Polish Workers' Party, Anita Prażmowska, biography, communist leadership.
\end{abstract}

This somehow ironic title might even sound better if finished with a question mark imbuing the readers with a sense of vagueness. Is it really better not to write a book or scientific paper at all than to publish material which still requires refinement, seems to be written hastily, without pondering or distancing oneself from the text, which is poorly structured and lacking reference to the available sources? One may disagree, but I personally believe that, after all, it works better to leave a topic unexplored than to publish a book which may do more harm than good. Such were my reflections while reading the latest monograph by Anita Prażmowska, professor of the world-renowned London School of Economics and Political Science. Until now, she has been known for

* Anita Prażmowska, Władysław Gomułka: A Biography, London and New York: I. B. Tauris, 2014 [2nd edn 2016], 296 pp., Communist Lives, vol. 7. Polish edition: Anita Prażmowska, Władysław Gomułka, Warsaw: Wydawnictwo RM, 2016, 296 pp. 
research on the history of the Second Republic of Poland and Polish-British relations in the interwar period and during the Second World War. ${ }^{1}$

However, she ventured to go beyond the year 1948 and write a complete biography of Władysław Gomułka. This is a worthwhile challenge in itself, considering the scarce number of biographies which demystify the period of the communist regime in Poland and the anticipation with which experts on the subject look forward to any publication of this type. Almost thirty years after the launch of the post-communist systemic transformation in Poland, as few as about twenty significant players on the political scene of the People's Republic of Poland have become the subjects of - better or worse - complete monographs. However, biographies, with their typically very clear inner structure - from birth to death - appeal most to general readers of historical books, and not just to researchers. Biographies owe their popularity, among other things, to their historical background. It is extremely important though to keep the right balance between the life story and description of the historical context. Last but not least, outstanding individuals - and with very few exceptions only such are immortalized in biographies - have always been of great interest to readers. The question of the degree to which an individual shaped the surrounding reality and the degree to which reality shaped them is always relevant.

Władysław Gomułka was probably the most influential of Poland's communist leaders. During the years 1943 to 1948 he held the office of secretary (from 1945 - secretary general) of the Polish Workers' Party (Polska Partia Robotnicza - PPR), and in 1956-70 - just over fourteen years - the office of first secretary of the Central Committee of the Polish United Workers' Party (Polska Zjednoczona Partia Robotnicza - PZPR). During the second half of the 1940s, he also held the office of deputy prime minister, with responsibility for the Regained Territories. In line with the leading idea of totalitarian systems, 'the more power, the more responsibility', Gomulka was co-responsible or even individually responsible for all the good and all the bad things that occurred in Poland during his terms of office.

In communist Poland Gomułka's name used to arouse a vivid social reaction and sometimes still does so today. He also provokes numerous controversies among historians of the recent past. Of all the Polish communist leaders, he was the one who sparked the most positive reaction among his colleagues, especially with reference to the period when he was the leader of the PPR. ${ }^{2}$

${ }^{1}$ Anita Prażmowska, Britain, Poland and the Eastern Front, 1939, Cambridge, 1987 (subsequent editions: 1989, 2004); eadem, Britain and Poland 1939-1943: The Betrayed Ally, Cambridge, 1995; eadem, Eastern Europe and the Origins of the Second World War, Basingstoke and New York, 2000; eadem, Civil War in Poland 1942-1948, New York: Palgrave Macmillan, 2004; eadem, A History of Poland, Basingstoke and New York, 2004 (2nd edn 2011); eadem, Poland: A Modern History, London and New York, 2010.

${ }^{2}$ The topic was first explored, with scientific aspirations, by Andrzej Werblan. However, as indicated in the title, the publication deals mostly with the period 1943-48 and finishes with Gomułka being arrested in 1951 (Andrzej Werblan, Władysław Go- 
These circles associate his name with the undefined and vague, yet catchy at the time, slogan: 'the Polish way to socialism'. His supporters emphasized that it was Gomułka who, at the September 1947 conference in Szklarska Poręba, showed a reserved, not to say reluctant, attitude towards Moscow's concept of creating the Information Bureau of the Communist and Workers' Parties (Cominform), which would in fact guard Soviet interests and constrain local - in this case Polish - communists. ${ }^{3}$ Moreover, it is generally remembered that Gomułka was consistently against the forcible collectivization of agriculture. As early as on 30 November 1946, he made a public statement saying: 'We refused to collectivize agriculture as an idea which, if implemented in Poland, would be economically and politically harmful'. ${ }^{4}$

Interestingly, reminiscencing over the period after Gomulka came back to power, praisers of his historical legacy frequently and willingly stress the role of 'Wiesław' in October 1956, but fail to show equal enthusiasm with reference to his role in the events of 1965-66,1968 and 1970. Therefore, materials written by representatives of those circles typically lack space for reflection on the reason why the Roman Catholic Church, and in particular the Primate of Poland, Cardinal Stefan Wyszyński, were treated extremely confrontationally during the anti-clerical propaganda campaign after the 'Pastoral Letter of the Polish Bishops to their German Brothers' (Orędzie biskupów polskich do ich niemieckich braci w Chrystusowym urzędzie pasterskim) had been issued, twenty years after the end of the Second World War, with the unforgettable words 'we forgive and ask for forgiveness'. ${ }^{5}$ Neither is there space for an analysis of the millennial celebration commemorating the anniversary of the Baptism of Duke Mieszko I, the first historical ruler of Poland, nor for a look back at the antisemitic and anti-intelligentsia campaign in the spring of 1968, nor for an insight into Gomułka's role in the pacification of the Prague Spring, nor for reflection on how it was possible that the same man who, coming back to power in 1956, explicitly censured the bloody suppression of the workers' protests in Poznan, did not hesitate to deem the workers' protests on the Baltic coast a counter-revolution and brutally pacify the protesters fourteen years later. Unfortunately, the Author of the work under review follows this trend to a large degree and fails to consider any of these issues. ${ }^{6}$

mutka sekretarz generalny PPR, Warsaw, 1988). The same period is described in volume one of Gomułka's biography entitled 'Wiesław' (the pseudonym used by Gomułka during the war - J.E.) by Maria Ewa Ożóg; volume two of the biography has never been published (Maria E. Ożóg, Władysław Gomułka. Biografia polityczna, Warsaw, 1989, vol. 1).

${ }^{3}$ Also referred to by Anita Prażmowska in the book under review: Prażmowska, Władysław Gomułka: A Biography, pp. 150-53; the Polish language version - pp. 146-49.

${ }^{4}$ Władysław Gomułka, W walce o demokrację ludowa, 2 vols, Warsaw, 1947, vol. 2, p. 162.

${ }^{5}$ Piotr Madajczyk, Na drodze do pojednania. Wokót orędzia biskupów polskich do biskupów niemieckich z 1965 roku, Warsaw, 1994; Sławomir Stępień, 'Sobór Watykański II i Orędzie Episkopatu Polski do biskupów niemieckich’, in Milenium czy Tysiąclecie, ed. Bartłomiej Noszczak, Warsaw, 2006, pp. 40-51.

${ }^{6}$ Prażmowska, Władysław Gomułka: A Biography, pp. 242-71; the Polish language version - pp. 222-50. 
Gomułka's co-workers and adherents take every opportunity to emphasize that, at least to a certain degree, he made Poland independent from the Soviet Union and, being rather traditional himself, contributed to the modernization and transition from an agricultural economy to an economy based on agriculture and industry. They do not forget his undoubted success - the Treaty of Warsaw, signed on 7 December 1970 between the People's Republic of Poland and the German Federal Republic, on the bases for the normalization of bilateral relations. ${ }^{7}$ In the West, Gomułka was sometimes pictured as a Polish communist who had the courage and willingness to oppose Iosif Stalin in 1948 and Nikita Khrushchev in 1956. Perhaps this is the reason why the Author devoted a large part of her work to foreign policy. This presents her with an opportunity to present how Gomulka 'stood up' to the Soviet Union in 1956 and the effort he made to have the border on the River Odra/Oder and Nysa Łużycka/ Neisse recognized internationally.

However, such a one-sided view is dangerously close to hagiography, and thus simply distorted. Selecting biographical facts which permit us to show an individual in the best light is pure manipulation. Any reference to Gomułka as a Polish 'national communist' should be accompanied by a commentary on how he himself understood it. In his Memoirs (Pamiętniki), written during his retirement years and published in two volumes post mortem (ed. Andrzej Werblan), which - unfortunately - finish in the year 1945 and do not discuss the post-war period, 'Wiesław' expressed his outrage at the arrest of sixteen leaders of the Polish Underground State and their abduction to Moscow by Soviets in the spring of 1945. However, he did not consider it lawless or treacherous. Here is his commentary on those events: 'The principle of sovereignty was brutally violated. It was an inexplicable intervention into Poland's domestic affairs, the authority of the government and the Party's management was undermined'. 8

${ }^{7}$ Of publications written in a benevolent tone, sometimes downright hagiographic, the following should be mentioned: Działalność Władysława Gomułki. Fakty. Wspomnienia. Opinie, selected and edited by Walery Namiotkiewicz, Warsaw, 1985; Jan Ptasiński, Drugi zwrot. Gomułka u szczytu powodzenia, Warsaw, 1988; idem, Pierwszy z trzech zwrotów, czyli rzecz o Władysławie Gomułce, Warsaw, 1983; Eleonora Syzdek and Bronisław Syzdek, Polityczne dylematy Władysława Gomułki, Warsaw, 1985; Władysław Gomułka i jego epoka, ed. Eleonora Salwa-Syzdek and Tadeusz Kaczmarek, Warsaw, 2005; Władysław Gomułka we wspomnieniach, ed. Bronisław Syzdek, Lublin, 1989; Piotr Zaborny, Władysław Gomułka: komunista, narodowiec, państwowiec, Skierniewice, 2006. See also the record of a discussion with several former co-workers of 'Wiesław' held on 6 December 1982 at the editorial office of Z Pola Walki quarterly in: Dyskusja o Władysławie Gomułce, Warsaw, 1984. It is interesting that, in spite of certain similarities in terms of ideological views between these authors and Prażmowska, no traces of most of these works can be found in the book under review.

8 'Została w sposób brutalny pogwałcona zasada suwerenności, nastąpiła niczym nie osłoniona interwencja w nasze wewnętrzne sprawy, poderwany został autorytet rządu i kierownictwa partii', Władysław Gomułka, Pamiętniki, vol. 2, ed. Andrzej Werblan, Warsaw, 1994, pp. 515-16. 
In his opinion the, sovereignty of the Polish state would have manifested itself if the abducted Poles had been put under trial and possibly sentenced by the court of what was still called the Republic of Poland, rather than by the Soviet tribunal. As an aside, if the 'Sixteen' had been sentenced by a Polish court, the judgments would have been much more severe and the death sentence might not have been avoided.

We must not forget that Gomułka, with his authoritarian character, could be referred to as anything but a democrat. When he returned to power in 1956, he explicitly spoke about democratization rather than about democracy. Real democracy, in classical terms, was beyond his comprehension. It was Gomułka who, as early as at the institution of the 'People's Poland', outlined the framework of the newly created system in the most explicit and clear-cut way. On 18 June 1945, during the talks in Moscow on the creation of the Provisional Government of National Unity, he addressed his political rivals and negotiation partners, who arrived from London in a delegation headed by Stanisław Mikołajczyk, former prime minister of the Polish government in exile, with the following meaningful words, which were later to be quoted on many occasions: ${ }^{9}$ 'Once we have power, we will never give it away. Not because anyone of us would like the power for himself. [...] We will not give it away to protect the Polish nation from the bane of the false political agenda which the reactionaries attempt to impose on the nation. [...] We shall destroy all the reactionary villains with scruple. You may keep shouting that the blood of Polish nation is being shed, that the NKVD rules Poland - it will not cause us to turn in our course'. ${ }^{10}$

It must be admitted that as a party activist and state official, Gomułka was consistent in his views. He was an autocrat, and at the same time an individual driven by various prejudices. For example, no rational explanation has yet been found for his well-known anti-intellectualism. It certainly cannot be put down entirely to his poor education, which entailed a lack of understanding of the specific egocentrism, characteristic of many intellectuals. He might have also been riddled by some insecurities of a 'Galician villager'. He had a strong conviction that bare knowledge, unsupported by life experience (including physical

9 'Władzy raz zdobytej nie oddamy nigdy. Nie dlatego, aby ktokolwiek z nas pragnął tego dla siebie, tej władzy. [...] Władzy nie oddamy dlatego, aby narodu polskiego nie spotkała nowa zguba, która mu grozi w wypadku fałszywej linii politycznej, którą próbuje narodowi narzucić reakcja. [...] Zniszczymy wszystkich bandytów reakcyjnych bez skrupułów. Możecie jeszcze krzyczeć, że leje się krew narodu polskiego, że NKWD rządzi Polską, lecz to nie zawróci nas z drogi', Gomułka was aware that this statement would immediately be communicated to the West and publicized there. This awareness might have been the reason for such an explicit and violent expression of his opinion on this matter.

${ }^{10}$ Rozmowy polityczne w sprawie utworzenia Tymczasowego Rządu Jedności Narodowej (June 1945), ed. Władysław Góra and Aleksander Kochański, Archiwum Ruchu Robotniczego, 9, 1984, p. 116. 
labour) is not worth much, as well as an ideologized view of the world divided into social classes. It is highly likely that he perceived intellectuals as relics from the previous system - 'layabouts' who never did any physical work. The time he spent imprisoned in Poland in the 1930s might have also shaped his perception.

It is interesting that those who defended his legacy often mentioned that in the era of the Second Republic of Poland Gomułka spent a total of several years in prison, but were rather reluctant to recall his imprisonment in 1951-54. There are several reasons for this, the most important one being the remorse and shame for having credited completely improbable charges put against 'Wiesław'. ${ }^{11}$ We cannot treat equally being imprisoned for political activity by adversaries or enemies and being imprisoned by one's own colleagues and moreover on groundless charges. ${ }^{12}$

Gomułka himself was probably also embarrassed about this situation. Having returned to power, he not only refused to right a wrong by acting against his oppressors - members of the same political party, but forbade any settling of accounts whatsoever. Incidentally, the Polish communists were not isolated in their silence about those events. Communists in other countries of the Soviet bloc also refused to speak about it. In the case of Gomulka, however, the refusal was significant insofar as he seemed to feel predestined to instruct and educate others, being at the same time, in spite of the influence of ideology, a pragmatist, realist and even a bit of a cynic.

Not infrequently, he patronized his colleagues, treating them with condescencion because he believed that he was always right. As his former colleagues reported later, ${ }^{13}$ he was a challenging partner in discussions, and persuading him about anything was next to impossible. He would be reluctant to change his lifetime opinion on many matters, and justified his actions believing not only that he was right, but also that he was the only person to save the Polish state from collapse. This is why he often dealt with minor issues in person and interfered in most aspects of public life. Arguably, in his opinion the Polish nation required a strong government to protect it from anarchy and the country from ruin. Undoubtedly, an individual as extraordinary as 'Wiesław' was cannot be reviewed in a simple and easy way. Therefore, it is even more surprising that among many publications dealing with his legacy, of various character and value (the first attempts to write his biography were made in the West while he was still holding the office of first secretary of the Central Committee of the

${ }^{11}$ For more on this matter, see: Andrazej Jaszczuk, Mit gomułkowszczyzny, Warsaw and Radzymin, 2011.

${ }^{12}$ The issue was discussed in detail by Robert Spałek (Robert Spałek, Komuniści przeciwko komunistom. Poszukiwanie wroga wewnętrznego w kierownictwie partii komunistycznej w Polsce w latach 1948-1956, Warsaw, 2014).

${ }^{13}$ Reported by Jerzy Albrecht in December 1988; reported by Artur Starewicz in December 1988; reported by Stanisław Trepczyński in June 1991 - to Jerzy Eisler. 
Polish United Workers' Party - KC PZPR), ${ }^{14}$ none deserves the name of an exhaustive scholarly biography. ${ }^{15}$

Having said that, it is quite understandable that the Polish edition of the work by Anita Prażmowska has met with lively interest in academic circles. The interest has been boosted by the fact that the work had been first published in the United Kingdom as part of the 'Communist Lives' series by Matthew Worley, featuring biographies of such well-known activists as Palmiro Togliatti, Maurice Thorez, Ernst Thälmann, Antonio Gramsci, Nicolae Ceaușescu, Imre Nagy, Georgi Dimitrov and Josip Broz Tito. However, anticipation was soon replaced by irritation among readers - Polish experts in modern history. First and foremost, the inner structure of the biography and the proportions in which the Author describes particular periods in Gomulka's life has met with fierce objections. Of the ten chapters,$^{16}$ only the three final ones and a short Epilogue refer to the key period in his life - the years 1956-70, when Gomułka was the leader of the PZPR, and in practice - the unquestioned 'Number One' in Poland. This amounts to less than eighty printed pages in a book which, together with the introduction, endnotes after each chapter, a list of abbreviations, references, and an index of names, has 296 pages. ${ }^{17}$

However, the structure of the book might not have aroused such strong irritation if not accompanied by other serious reservations. The critics did take into consideration the fact of utmost importance, namely that the biography was not targeted at Polish readers. Therefore, they spared the Author criticism for certain unavoidable simplifications or explanations of issues to Anglophone readers which are obvious to the Poles and might seem unnecessary, redundant or superfluous, but which in fact are not. Even an academic reader in the United Kingdom might not have sufficient background knowledge of the modern history of Poland to contextualize the life of Gomułka. Nevertheless, an author of a historical monograph is obliged to comply with such

${ }^{14}$ In 1969, two authors, independently of each other, published works on Gomułka: Nicholas Bethell (Nicholas Bethell, Gomulka. His Poland and His Communism, London, 1969) and Peter Raina (Peter K. Raina, Władysław Gomułka. Życiorys polityczny, London, 1969).

${ }^{15}$ Twenty years after its publishing date, the work by Paweł Machcewicz published in the popular Dzieje PRL series remains the most exhaustive complete biography of 'Wiesław' (Paweł Machcewicz, Władysław Gomułka, Warsaw, 1995). For more recent publications, see: Jerzy Eisler, 'Władysław Gomułka', in idem, Siedmiu wspaniałych. Poczet pierwszych sekretarzy KC PZPR, Warsaw, 2014, pp. 167-251. Robert Spałek is currently working on a complete scientific biography of 'Wiesław'.

${ }^{16}$ The book consists of: 'Introduction', Chapter 1: 'Family and Early Childhood'; Chapter 2: 'Political Maturing'; Chapter 3: 'The 1930s and Entry into National Politics'; Chapter 4: 'The Reconstruction of the Polish Communist Party During the Second World War'; Chapter 5: 'From Conspiracy to Power in Postwar Poland'; Chapter 6: '1944-8: The Establishment of Communist Power in Poland'; Chapter 7: '1948-56: The Dark Years'; Chapter 8: 'The People's Secretary'; Chapter 9: 'The Polish Road to Socialism'; Chapter 10: 'Nemesis'; ‘Epilogue'.

${ }^{17}$ In the Polish edition, the endnotes are compiled together at the end of the book. 
fundamental principles of scholarly research as seeking the truth, pursuing the highest possible objectivity in judgements, using a neutral, unemotive language of description, not stigmatizing those who - rightly or wrongly - may be deemed enemies of the researcher, clearly distinguishing between facts and hypotheses or research postulates, and, last but not least, using all available and relevant historical sources and the latest literature on the subject. I am not the only person to question, more than anything else, the Author's compliance with these principles of research. ${ }^{18}$

The references listed in the biography give evidence for research done in the Central Archives of Modern Records (AAN), the Archive of the Institute of National Remembrance (IPN), the Archive of the Union of Polish Writers (ZLP), the Archives of the Ministry of Foreign Affairs (MSZ) in Warsaw, the Archives of the Ministry of National Defence (MON) in Modlin, and the Russian State Archives of Social and Political History (RGASPI). However, a more detailed examination of the footnotes reveals that while sources found in the AAN are referred to on many occasions, those found in the IPN are cited only a few times, whereas scarce references are made to sources originating from the RGASPI or the Archives of the ZLP. Interestingly, I found no reference whatsoever in the endnotes to any sources from the Archives of the MSZ or the MON.

Moreover, the Author refers to records from the AAN when citing documents which, published many years ago, are in the public domain and so available not only to researchers. For instance, in footnotes 51-55 of the English language version (54-58 in the translation into Polish) of Chapter 10, Prażmowska refers to archival records of shorthand notes of the meeting of first secretaries of provincial committees of the PZPR at the seat of the KC PZPR on 26 March 1968, whereas the same document, edited by Andrzej Garlicki, was published in print almost twenty-five years ago. ${ }^{19}$ Similarly, in footnotes $56-58$ (English version) or 59-62 (Polish edition) in the same chapter, the Author refers to a record of minutes from the meeting of the Political Bureau and a note on the discussion held at the meeting of 8 April 1968, available in the archives of the AAN, whereas, at least in the case of the latter document, she should have made a reference to another publication edited by Andrzej Garlicki. ${ }^{20}$ Certainly, Anita Prażmowska had every right to refer to archival records, but at the same time, she was first and foremost obliged to make references to publicly available printed versions of those documents.

However, the most objectionable aspects of the text are dozens of factual errors, ill-considered and unjustified judgements and opinions, excessive sim-

18 See for example: Michał Przeperski, ‘Anita Prażmowska - “Władysław Gomułka” - recenzja', Histmag.org, 1 December 2016 〈https://histmag.org/Anita-Prazmowska -Wladyslaw-Gomulka-recenzja-14374〉 [accessed 20 February 2017]; Tomasz Siewierski, 'Nieudana próba historiograficznej humanizacji', Nowe Książki, 2017, 4, pp. 74-75.

${ }^{19}$ Andrzej Garlicki, 'Władysław Gomułka o marcu 1968', PH, 84, 1993, 4, pp. 499-518.

20 'Biuro Polityczne proponuje', in Andrzej Garlicki, Z tajnych archiwów, Warsaw, 1993, pp. 336-58 (first publ. in Polityka, 1991, 23). 
plifications and hasty generalizations. There is no space here for enumerating all the errors and flaws I have spotted (needless to say, the list would not be exhaustive). To start with the Introduction, the Author states: 'During the period 1947-56 there was very limited scope for Polish Communist leaders to do anything other than apply the Soviet model in Poland, all the time trying to anticipate what more was expected of them' (p. XIV; p. 8 in the Polish version).

An ironic question arises here - does it really mean that, in the Author's opinion, Polish communists had more freedom of action in the years 1944-47 than later? If so, this is extremely controversial considering that for many years, the Polish historians have been familiar with the fact that the most violent, bloody and villainous terror took place in the first year $-1944-45 .{ }^{21}$ Reportedly, the Soviets played the leading role in Poland in that time and owing to their presence, the Polish communists could little by little assume power in the territories liberated from the occupation of Nazi Germany. Millions of Soviet soldiers swept through the country within the borders agreed at the Yalta Conference, on their march to Berlin and back to the Soviet Union, actively supported by the 62nd, 63rd and 64th divisions of the NKVD, combating the anti-communist partisan groups. ${ }^{22}$ The 64th division of the NKVD operated in Poland until the spring of 1947. It is also difficult to forget that the three most important political activists of the time, President Bolesław Bierut, prime minister premier Edward Osóbka-Morawski and Władysław Gomułka, used the security services provided by the Sixth Directorate of the People's Commissariat for State Security (NKGB). ${ }^{23}$

${ }^{21}$ Andrzej Paczkowski, historian and expert on the topic, once expressed his opinion that the cruelty of the terror which prevailed when the communist power was first established in Poland and its crippling effect on the Polish society, harrowed by the war and occupation, had far-reaching consequences. As a result, in the years to come, communists did not need to rely on harassment and repression on such a scale as in other countries which, in the aftermath of the Second World War, were within the zone of absolute Soviet domination. The bloody 'terror of the first year' resulted in a relatively less cruel system in Poland during the period when Stalinism was most strictly enforced (after 1948) in other countries of the Soviet bloc, which certainly is no reason for glorifying the Polish communists. Krystyna Kersten was the first to note the significance of the 'terror of the first year' thirty years ago, on the pages of Aneks issued in London (Krystyna Kersten, 'Terror na przełomie wojny i pokoju, lipiec 1944-lipiec 1945’, Aneks, 1988, 51/52, pp. 92-121). For more recent publications, see: Rok pierwszy. Powstanie i działalność aparatu bezpieczeństwa publicznego na Lubelszczyźnie (lipiec 1944-czerwiec 1945), ed. Leszek Pietrzak et al., Warsaw, 2004; Rok pierwszy. Powstanie i działalność aparatu bezpieczeństwa publicznego na Rzeszowszczyźnie (sierpień 1944-lipiec 1945), ed. Dariusz Iwaneczko, Zbigniew Nawrocki, Rzeszów, 2005.

${ }^{22}$ It must be explicitly stressed that in Poland, those partisan groups dated back to the years of resistance against the Nazi Germany.

${ }^{23}$ A letter by Lavrentii Beria to I. Stalin and Viacheslav Molotov, notifying the security services provided to B. Bierut, W. Gomułka and E. Osóbka-Morawski was handed over by the People's Commissariat for State Security to the Polish security authorities, in Teczka specjalna J. W. Stalina. Raporty NKWD z Polski 1944-1946, ed. Tatiana Cariewskaja et al., Warsaw, 1998, p. 347. 
However, some of the Author's opinions seem to have been formulated imprecisely, and thus erroneously. For instance, on page XV (p. 9 in the Polish edition), the following statement about Gomułka is found: 'His role during the years 1945 to 1951 is difficult to discern, because of the complexities of Soviet actions in relation to Poland'. Firstly, Gomułka's role was incomparably more important during the years 1945 to 1948 than in the following period, when he was gradually removed from the positions and functions he held, sidelined and deprived of actual power, before he was finally arrested in August 1951. Therefore, in practice, the role of 'Wiesław' in those two periods cannot be compared. Secondly, is Prażmowska really of the opinion that due to the complex nature of the Polish-Soviet relations, which in fact had always been 'complex', an evaluation of the real role of Gomułka in that time is challenging? What does the one have to do with the other and what does it all mean?

In line with the watchword 'the more power, the more responsibility' referred to above, Gomułka, as secretary general of the PPR, deputy prime minister and minister for the 'regained territories', should be held at least co-responsible for all the developments in Poland during the years 1945 to 1948. On the same page, the Author makes an equally imprecise statement: 'In 1956 Poles were allowed by the Soviet leadership to choose their own party leader'. The statement may lead to a wrongful conclusion that Gomulka was elected first secretary of the KC PZPR in general elections, whereas in reality, only members of the Central Committee were eligible to vote, and the candidate still needed the approval of the Kremlin. Similarly, no serious consideration can be afforded to the Author's opinion that in the summer of 1956 Po Prostu weekly 'openly called for Gomułka to be appointed as party secretary', (p. 196; p. 183 in the Polish version). Would anything like that be possible in a country where preventive censorship applied to anything that was to be published? Any speculation about the upcoming developments and their possible consequences, so typical for democratic countries, were in practice out of the question in countries ruled by communist regimes.

The Author seems to overrate the scope and scale of freedom of speech in Poland in the summer and autumn of 1956, when 'the editorial boards of all publications operated without any constraints, either from the party or from the censors' (p. 226; p. 210 in the Polish edition). We must remember that the margin of freedom of speech in Poland was extended at this time, but it was still only a margin. No statutory restrictions were imposed on censorship, which was pursued anonymously and in secret - any cuts made by the censors had to be scrupulously hidden. It suffices to mention here that the press release commenting on the June rebellion in Poznan on the pages of Po Prostu, the most progressive weekly magazine of the time, was re-edited nineteen times until it was approved by the censors. ${ }^{24}$

I am uncertain as to what the Author meant when she, having rightfully stated that 'Events unfolding in Poland were part of a trend which affected all

${ }^{24}$ Barbara N. Łopieńska and Ewa Szymańska, Stare numery, London, 1986, pp. 55-56. 
the countries of the Socialist bloc since Stalin's death' (p. 207; p. 194 in the Polish edition), added as follows: 'The first foreign policy dilemma which confronted the Poles was in relation to Yugoslavia'. Does she really mean that even as regards foreign policy, during the years 1953 to 1954 Poland was not challenged by any issues more serious than the relations with Yugoslavia? This is hard to agree with, bearing in mind, for example, the process of gradual Destalinization of Poland, following the same phenomenon in the Soviet Union after Stalin's death.

As mentioned before, the work is riddled with linguistic errors and major or minor flaws. For instance, on page 69 (p. 76 in the Polish edition), the Author falsely states that Gomułka and General Karol Świerczewski, who had trained Gomułka in the 1930s in the Soviet Union, met up again after the war. In fact, they met up in 1944, that is, before the Second World War finished. Marian Spychalski in turn - contrary to Świerczewski - was not a "veteran of the Spanish Civil War' (p. 91; p. 95 in the Polish edition). Despite what is written on page 201 (p. 188 in the Polish edition), Stefan Staszewski, first secretary of the Warsaw Committee of the PZPR, neither in October 1956, nor at any other time, was a member of the Political Bureau of the KC PZPR. On two occasions (pp. 229 and 231; p. 212 and 214 in the Polish edition), the Author falsely claims that the Third Convention of the PZPR was held in 1958, whereas in fact it was held in March 1959.

In footnote 33 (n. 32 in the Polish edition) to Chapter 2, the Author misleads the reader stating that on 1 August 1951 Gomułka and his wife "were interned by the Party Central Control Commission, which was also known as the Department X'. Firstly, they were interned on the second rather than the first day of August. Secondly, the Party Central Control Commission was neither the Tenth Department of the Ministry of Public Security, nor - as stated in the Polish edition, after an equally unsuccessful attempt at correction - did it supervise the operation of the Ministry of Public Security. Last but not least, the Tenth Department of the Ministry of Public Security did not even exist when Władysław and Zofia Gomułka were arrested (by officers of the Special Bureau). It awas established a few months later, as a result of the reorganization of the Ministry of Public Security. ${ }^{25}$

The Author dedicates her work to Margaret and Max Morris, presenting them to the reader (in the order as follows) as communists, educationalists and first and foremost her friends. Regardless of the dedication, which, in fact, is at the same time an ideological declaration, and regardless of a possible communist or radical left-wing attitude, no researcher's own outlook on life should serve as an excuse for shortcomings in scholarly criticism, scepticism, linguistic precision

${ }^{25}$ In the recent years, a vast amount of literature has been published on the subject in Poland. Apart from the fundamental monograph by Robert Spałek, Komuniści przeciwko komunistom, referred to in n. 13, see, without reserve: Departament X MBP: wzorce, struktury, działanie, ed. Konrad Rokicki, Warsaw, 2007; Jacek Topyło, Departament X MBP w latach 1949-1954: geneza, struktura organizacyjna, metody pracy, Warsaw, 2006. See also: Andrzej Paczkowski, Trzy twarze Józefa Światty: przyczynek do historii komunizmu w Polsce, Warsaw, 2009. 
or responsibility for the published material. Referring to victims of Stalin's 'Great Purge' among members of the Communist Party of Poland, the Author writes: 'The list of victims was long and included distinguished Communists who had established the party in Poland and who had participated in the great ideological debates. Warski and Kostrzewa were among those who perished' ${ }^{26}$ It seems very unlikely that a serious academic historian in modern Poland would refer to Adolf Warski and Wera Kostrzewa as 'distinguished communists' participating in 'great ideological debates'.

Similarly, it seems unclear why Prażmowska writes that little is known about the manpower and structure of the People's Guard (GL) in the initial years of the war (p. 105). For an unknown reason, the Polish edition (p. 106) has it more precisely - 'during the first two years of the war'. In fact, the GL was formed in 1942 and, indeed, little is known about its manpower and structure 'during the first two years of the war', simply because it was not yet in existence. Perhaps, following Soviet researchers, the Author considers the beginning of the Great Patriotic War of the Soviet Union in June 1941 (as it used to be referred to in the Soviet Union and is still referred to in Russia, always written with capital letters) the outbreak of the Second World War. If so, there is some information available about the manpower and structure of the GL 'during the first two years of the war'. I do not understand, however, why, on several pages, Prażmowska refers to Gomułka's Diaries as an 'autobiography'. In spite of certain similarities, a diary and an autobiography are two different literary genres.

Unfortunately, most of the linguistic flaws were transferred to the Polish translation and as a result, the work by Katarzyna Skawran (translator) is far from perfect. For instance, it is difficult to explain the use of words and phrases originating from propaganda brochures in communist Poland, such as 'Piłsudski's clique' or 'Piłsudski's coterie'. Even more irritating is the reference to 'liberated Lublin' (p. 109 in the Polish edition) rather than to Lublin liberated from the German occupation, as it should be properly referred to. It has been common knowledge for a long time that for many (or maybe for the majority of) Poles, the 'liberation' of Poland by the Red Army meant a transition from the German occupation to the Soviet occupation, and entailed the establishment of the communist regime.

On page 122 (p. 121 in the Polish edition) the Author seems to be clearly 'lost'. She writes: 'On 20 July the KRN was officially transformed into a Polski Komitet Wyzwolenia Narodowego (Polish Committee of National Liberation PKWN). In its capacity as a designated provisional government, it opened talks with the Soviet authorities which led to agreements on Poland's borders'. It is a well-known fact that the KRN did not transform into the PKWN but rather founded the PKWN, together with the PPR activists from the occupied country and members of the Central Bureau of Polish Communists of Poland, at a meet-

${ }^{26}$ Prażmowska, Władysław Gomułka: A Biography, p. 73; p. 80 in the Polish edition. 
ing in Moscow. This serious mistake results from frequent references to older works, published in communist Poland.

Anyone who might think that this is 'merely' a linguistic slip will find the following text on the following page: 'With the Red Army's Progress into Polish territories, the first delegation of the PKWN arrived in the liberated town of Chełm on 22 July'. This single sentence requires several serious clarifications. Firstly, the Soviet army did not enter the territory of the Polish state having crossed the River Bug in July 1944. Instead, the front-line units of the Red Army entered the Polish territory on the night of 3-4 January 1944 near Rokitno, west of Sarny, when they crossed the pre-war Polish state border. The border was established in 1921 under the Treaty of Riga signed by Poland and Soviet Russia. For the first time, the Soviets crossed that border in September 1939, carrying out an attack on Poland engaged in a lone fight with the Third Reich. Secondly, members of the PKWN - contrary to the legend perpetuated in Poland during the communist regime - did not arrive in Chełm on 22 July, but were transported there onboard Soviet aircraft as late as in the afternoon of 27 July 1944. Equally false is the information on page 124 (pp. 123-24), saying that in January 1945 the PKWN was transformed into the Provisional Government of National Unity (TRJN). In fact, the TRJN came into existence in June 1945 following the Moscow talks on its establishment, attended by, among others, the former prime minister in exile, Stanisław Mikołajczyk. In turn, on 31 December 1944 (rather than in January 1945) the PKWN was transformed into the Provisional Government.

By the way, there are many references in the Polish text to 'émigré government' instead of the significantly longer, but proper form 'the government-in-exile of the Republic of Poland'. The fact must be considered not only in terms of linguistic precision. The latter expression describes the lawful, internationally recognized government of Poland operating (temporarily) in exile. On the other hand, the the propaganda expression, promoted during the communist regime, 'émigré government' was meant to marginalize its significance - one might think that was just a 'sofa' government of little importance.

What is more, the commonly used (also in many scholarly publications) but highly improper term 'Generalna Gubernia' should not be used under any circumstances. The only proper form is 'Generalne Gubernatorstwo' (Generalgouvernement in German). By the way, Prażmowska uses the term General Government in the English version. In turn, both in the Polish and the English version, the term Red Army can be found with reference to the post-war armed forces of the Soviet Union, in spite of the fact that in February 1946 their official name was changed to the Soviet Army, and only this term should be used in texts whose authors aspire to the title of scholarly writers.

On the other hand, the translator, together with the editor of the Polish edition Wojciech Markert, merit praise for correcting certain minor flaws of the Author. For instance, it can be read on page 87 of the English edition that in October 1939, the Polish government-in-exile was established in France. The information 
was rectified in the Polish version (p. 91), where we read that the (properly named) Polish government-in-exile, led by General Władysław Sikorski, came into existence on 30 September 1939. Unfortunately, the translator and/or editors of the Polish version did not avoid the introduction of new errors into the text. For instance, Anita Prażmowska writes on page 199, correctly, that in October (although it was - in fact - November) 1944 Konstanty Rokossowski was appointed Polish minister of national defence. In the Polish edition (p.186), a false note was added that Rokossowski still held the rank of general, whereas in fact, he was promoted to marshal of the Soviet Union in June 1944. Similarly, on page 225 of the Polish edition, a note was added, for an unknown reason, that Leonid Brezhnev held the function of first secretary of the Central Committee of the Communist Party of the Soviet Union, whereas in fact he held the title of secretary general. This fact is not insignificant when speaking about such a persona. Enough examples.

I have mentioned above that what I object to most in this book are 'dozens of factual errors, ill-considered and unjustified judgements and opinions, excessive simplifications and hasty generalizations'. However, equally objectionable for me is its general ideological and political overtone. To make myself clear, I am not of the opinion that a historian and researcher is deprived of the right to express any political views. However, I do not consider the pages of a scholarly book to be the right space for such an expression. Anita Prażmowska has openly expressed her political views and affinity in Gomułka's biography, thus creating an image of Gomułka (and of Poland under his government) which has little in common with that arising from other publications belonging to modern Polish historiography.

The reader must have realised by now that we are dealing here with a book written carelessly, with many major errors, controversial judgements and over-simplifications. What is more, considering certain mistakes and obvious errors, it is difficult to resist the impression that the Author does not feel confident about her knowledge of the topic she chose to tackle. She might have overestimated her abilities, or found that she was able to write a biography of such an extraordinary and game-changing for the communist movement personality as Gomułka, ${ }^{27}$ targeted at English-speaking readers. If so, I must admit that she failed to prepare meticulously for the job. First and foremost, she makes no reference to works which reveal the most important facts from the biography of 'Wiesław'. Sources authored by experts in Poland's modern history, such as Dariusz Jarosz, Andrzej Garlicki (mentioned solely as the biographer of Józef Piłsudski), Krystyna Kersten, Marcin Kula, Mariusz Mazur, Andrzej Paczkowski, Rafał Wnuk, or of the younger generation - Robert Spałek or Mirosław Szumiło, are not referred to at all. Very little reference is made to publications by Antoni Dudek, Andrzej Friszke, Paweł Machcewicz (first and foremost, the popular biography of Gomułka mentioned in

${ }^{27}$ As a result, the risk arises that the false, downright mendacious image of Gomułka created by the Author may become popular in Western historiography. 
footnote 15), Piotr Osęka, Dariusz Stola, or, last but not least, my own work, apart from the monograph of $1968,{ }^{28}$ listed in the references and referred to in one footnote only. At least three other of my books (or books which I co-authored) would have been useful in the work on Gomulka's biography. ${ }^{29}$

No more use has been made by the Author of diaries of former party and state activists - suffice it to mention the ten-volume Dzienniki polityczne of Mieczysław F. Rakowski. There is no trace of reference to memoirs by Kazimierz Barcikowski, Edward Gierek, Piotr Jaroszewicz, Wojciech Jaruzelski, Stanisław Kania, Czesław Kiszczak, Franciszek Szlachcic or Józef Tejchma. In this context, as well as in the context of what I have written above, it must be stated that in practice, the Author was doomed to... failure. In my opinion, with such gaps in the source base and more recent literature of the subject, there was no chance whatsoever for a decent biography of Władysław Gomułka. With reference to the title of this article, I cannot conclude otherwise but repeat that it would have been better if the book had never been written, than written as it is: better not at all than not well.

(Translated by Paulina Dzwonnik)

\section{Summary}

Władysław Gomułka was the Polish communist leader who, most probably, played the most important role in the history of Poland. In the years 1943-48 he was the Secretary of the Polish Workers' Party, and next, from 1956 to 1970, the First Secretary of the Central Committee of the Polish United Workers' Party. According to the rule 'the more power the more responsibility', which had particular significance in non-democratic systems, Gomułka was responsible or co-responsible for everything good but also for everything bad that happened in Poland during his rule. At the same time, his name used to cause, and sometimes still causes, active reactions. It happens also due to the publication of over twenty books on his activity. One of the recent ones was published by Anita Prażmowska, the Professor at the London School of Economics and Politics. Unfortunately, because of numerous errors, inaccuracies, simplifications and generalizations it is by no means a successful attempt, which I try to prove in my review of this book.

(Translated by Elżbieta Petrajtis-O’Neill)

\footnotetext{
${ }^{28}$ Jerzy Eisler, Polski rok 1968, Warsaw, 2006.

${ }^{29}$ Apart from the material on first secretaries of the KC PZPR, mentioned in n. 15, references should be made to the following publications: Jerzy Eisler, Grudzien 1970. Geneza, przebieg, konsekwencje, 2nd edn, revised and supplemented, Warsaw, 2012; Jerzy Eisler and Stanisław Trepczyński, Grudzień '70 wewnątrz 'Białego Domu', Warsaw, 1991.
} 


\section{Bibliography}

Bethell, Nicholas, Gomułka. His Poland and His Communism, London: Longman, 1969.

‘Biuro Polityczne proponuje’, in Andrzej Garlicki, Z tajnych archiwów, Warsaw: Polska Oficyna Wydawnicza BGW, 1993, pp. 336-58.

Departament X MBP: wzorce, struktury, działanie, ed. Konrad Rokicki, Warsaw: Instytut Pamięci Narodowej - Komisja Ścigania Zbrodni przeciwko Narodowi Polskiemu, 2007.

Dyskusja o Władysławie Gomułce, Warsaw: Wyższa Szkoła Nauk Społecznych przy KC PZPR, 1984.

Działalność Władysława Gomułki. Fakty. Wspomnienia. Opinie, selected and edited by Walery Namiotkiewicz, Warsaw: Książka i Wiedza, 1985.

Eisler, Jerzy, Grudzień 1970. Geneza, przebieg, konsekwencje, 2nd edn, revised and supplemented, Warsaw: Instytut Pamięci Narodowej - Komisja Ścigania Zbrodni przeciwko Narodowi Polskiemu, 2012.

Eisler, Jerzy, Polski rok 1968, Warsaw: Instytut Pamięci Narodowej - Komisja Ścigania Zbrodni przeciwko Narodowi Polskiemu, 2006.

Eisler, Jerzy, 'Władysław Gomułka', in idem, Siedmiu wspaniałych. Poczet pierwszych sekretarzy KC PZPR, Warsaw: Wydawnictwa Szkolne i Pedagogiczne, 2014, pp. 167-251.

Eisler, Jerzy, and Stanisław Trepczyński, Grudzień '70 wewnątrz 'Białego Domu', Warsaw: Colibri, 1991.

Garlicki, Andrzej, ‘Władysław Gomułka o marcu 1968', Przegląd Historyczny, 84, 1993, 4, pp. 499-518.

Gomułka, Władysław, Pamiętniki, 2 vols, ed. Andrzej Werblan, Warsaw: Polska Oficyna Wydawnicza BGW, 1994.

Gomułka, Władysław, W walce o demokrację ludowa, 2 vols, Warsaw: Książka, 1947.

Jaszczuk, Andrzej, Mit gomułkowszczyzny, Warsaw and Radzymin: Wydawnictwo von borowiecky, 2011.

Kersten, Krystyna, ‘Terror na przełomie wojny i pokoju, lipiec 1944-lipiec 1945', Aneks, 1988, 51/52, pp. 92-121.

Łopieńska, Barbara N., and Ewa Szymańska, Stare numery, London: Aneks, 1986.

Machcewicz, Paweł, Władysław Gomułka, Warsaw: Wydawnictwa Szkolne i Pedagogiczne, 1995.

Madajczyk, Piotr, Na drodze do pojednania. Wokół orędzia biskupów polskich do biskupów niemieckich z 1965 roku, Warsaw: Wydawnictwo Naukowe PWN, 1994.

Ożóg, Maria Ewa, Władysław Gomułka. Biografia polityczna, Warsaw: Wydawnictwo Spółdzielcze, 1989, vol. 1.

Paczkowski, Andrzej, Trzy twarze Józefa Światły: przyczynek do historii komunizmu w Polsce, Warsaw: Prószyński Media, 2009.

Prażmowska, Anita, Britain and Poland 1939-1943: The Betrayed Ally, Cambridge: Cambridge University Press 1995. 
Prażmowska, Anita, Britain, Poland and the Eastern Front, 1939, Cambridge: Cambridge University Press, 1987 (subsequent editions: 1989, 2004).

Prażmowska, Anita, Civil War in Poland 1942-1948, New York: Palgrave Macmillan, 2004.

Prażmowska, Anita, A History of Poland, Basingstoke and New York: Palgrave Macmillan, 2004 (2nd edn 2011).

Prażmowska, Anita, Eastern Europe and the Origins of the Second World War, Basingstoke: Macmillan; New York: St. Martin's Press, 2000.

Prażmowska, Anita, Poland: A Modern History, London and New York: I. B. Tauris, 2010.

Prażmowska, Anita, Władysław Gomułka, Warsaw: Wydawnictwo RM, 2016.

Prażmowska, Anita, Władysław Gomułka: A Biography, London and New York:

I. B. Tauris, 2014 (2nd edn 2016), Communist Lives, vol. 7.

Przeperski, Michał, 'Anita Prażmowska - "Władysław Gomułka” - recenzja', Histmag.org, 1 December 2016 〈https://histmag.org/Anita-Prazmowska -Wladyslaw-Gomulka-recenzja-14374〉 [accessed 20 February 2017].

Ptasiński, Jan, Drugi zwrot. Gomułka u szczytu powodzenia, Warsaw: Krajowa Agencja Wydawnicza, 1988.

Ptasiński, Jan, Pierwszy z trzech zwrotów, czyli rzecz o Władysławie Gomułce, Warsaw: Krajowa Agencja Wydawnicza, 1983.

Raina, Peter K., Władysław Gomułka. Życiorys polityczny, London: Polonia Book Fund, 1969.

Rok pierwszy. Powstanie i działalność aparatu bezpieczeństwa publicznego na Lubelszczyźnie (lipiec 1944-czerwiec 1945), ed. Leszek Pietrzak et al., Warsaw: Instytut Pamięci Narodowej - Komisja Ścigania Zbrodni przeciwko Narodowi Polskiemu, 2004.

Rok pierwszy. Powstanie i działalność aparatu bezpieczeństwa publicznego na Rzeszowszczyźnie (sierpień 1944-lipiec 1945), ed. Dariusz Iwaneczko, Zbigniew Nawrocki, Rzeszów: Instytut Pamięci Narodowej - Komisja Ścigania Zbrodni przeciwko Narodowi Polskiemu, 2005.

Rozmowy polityczne w sprawie utworzenia Tymczasowego Rzadu Jedności Narodowej (June 1945), ed. Władysław Góra and Aleksander Kochański, Archiwum Ruchu Robotniczego, 9, 1984, pp. 100-55.

Siewierski, Tomasz, 'Nieudana próba historiograficznej humanizacji', Nowe Książki, 2017, 4, pp. 74-75.

Spałek, Robert, Komuniści przeciwko komunistom. Poszukiwanie wroga wewnętrznego w kierownictwie partii komunistycznej w Polsce w latach 1948-1956, Warsaw: Zysk i S-ka; Warsaw: Biuro Edukacji Publicznej IPN. Oddział, 2014.

Stępień, Sławomir, ‘Sobór Watykański II i Orędzie Episkopatu Polski do biskupów niemieckich', in Milenium czy Tysiąclecie, ed. Bartłomiej Noszczak, Warsaw: Instytut Pamięci Narodowej - Komisja Ścigania Zbrodni przeciwko Narodowi Polskiemu, 2006, pp. 40-51.

Syzdek, Eleonora and Bronisław Syzdek, Polityczne dylematy Władysława Gomułki, Warsaw: Czytelnik, 1985. 
Teczka specjalna J.W. Stalina. Raporty NKWD z Polski 1944-1946, ed. Tatiana Cariewskaja et al., Warsaw: Instytut Studiów Politycznych Polskiej Akademii Nauk, 1998.

Topyło, Jacek, Departament X MBP w latach 1949-1954: geneza, struktura organizacyjna, metody pracy, Warsaw: Wydawnictwo Adam Marszałek, 2006.

Werblan, Andrzej, Władysław Gomułka sekretarz generalny PPR, Warsaw: Książka i Wiedza, 1988.

Władysław Gomułka i jego epoka, ed. Eleonora Salwa-Syzdek and Tadeusz Kaczmarek, Warsaw: Wydawnictwo Studio Emka, 2005.

Władysław Gomułka we wspomnieniach, ed. Bronisław Syzdek, Lublin: Wydawnictwo Lubelskie, 1989.

Zaborny, Piotr, Władysław Gomułka: komunista, narodowiec, państwowiec, Skierniewice: Wydawnictwo Sigma, 2006.

Biography: Jerzy Eisler - Professor at the Tadeusz Manteuffel Institute of History of the Polish Academy of Sciences in Warsaw; Director of the Warsaw branch office of the Institute of National Remembrance - Commission for the Prosecution of Crimes against the Polish Nation (IPN); scholarly interests: political history of the France and Poland in the twentieth century, history of communism, history of military affairs. E-mail: jerzy.eisler@ipn.gov.pl. 